\title{
Anatomical and histological characterization of the gametogenesis of Radix balthica (linnaeus, 1758) in comparison with Lymnaea stagnalis (linnaeus, 1758)
}

Khedidja Tair-Abbaci ${ }^{*}$, Sandrine Joachim² ${ }^{2}$ Jeanne Garric ${ }^{1}$, Paul Boisseaux', Jean-Marie Exbrayat ${ }^{3}$, Jean-Marc Porcher² and Olivier Geffard ${ }^{1}$

*Correspondence: khedidja.abbaci@irstea.fr

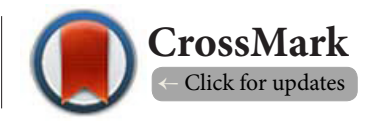

'Irstea, UR MALY, Lyon-Villeurbanne center, 5 rue de la Doua, BP 32108, 69616 Villeurbanne Cedex, France.

${ }^{2}$ National Institute of Industrial Environment and Risks (INERIS), ECOT (In Vitro and In Vivo Ecotoxicology) Unit, UMR-I 02 SEBIO, B.P. 2, 60550 Verneuil-en-Halatte, France.

${ }^{3}$ Laboratory of General Biology, UCLy; Laboratory of Reproduction and Development Compare, EPHE; UMRS 449, Catholic University, 10 Place des Archives, 69288 Lyon Cedex 022, France.

\begin{abstract}
Freshwater gastropods are frequently used as model organisms to assess the effects of certain chemical substances. Among them Radix balthica and Lymnaea stagnalis are commonly used in the laboratory, mesocosm and fields tests. In order to determine the effects of pollutants and more particularly endocrine disrupting substances on the reproduction of these organisms, histopathological analyses can be used. Because data are still scarce in the literature, knowledge development on anatomy of reproductive tissues and gametogenesis is a preliminary step before any studies on the impact of contaminants on the reproduction of these gastropods. The characterization of the anatomy and gametogenesis of Radix balthica and Lymnaea stagnalis was thus performed in this study. Important morphological differences exist between the two species. Despite this, the gonads of the two gastropods species have similar histological structure. In both species, spermatogonia are clustered; spermatozoids are anchored in the Sertoli cells and the male cells alternate with the female cells that rest on the epithelium of the hermaphroditic gland. This study is a prerequisite for any further histopathological studies on contaminated individuals.
\end{abstract}

Keywords: Anatomy, histology, gametogenesis, Radix balthica, Lymnaea stagnalis

\section{Introduction}

Gastropods are epibenthic organisms which are distributed in many types of aquatic ecosystems preferring lentic and brackish waters located near fields [8]. Considering their habitat preferences, they are directly exposed to pesticides and herbicides [20]. They become relevant ecological indicators and they are frequently used for water quality surveillance and monitoring [28] and in ecotoxicological bioassays [4,16].

As gastropods have a wide range of reproductive strategies (hermaphroditism, gonochorism, parthenogenesis) and feeding behavior, they are relevant models enabling to study the effects of endocrine disrupting chemicals [24]. Exposure of certain species of gastropods to TBT (tributyltin) at sub-lethal concentrations ( $\mathrm{ng} / \mathrm{L}$ ), have lead to metabolic modifications $[23,25,32]$. Effects of BPA (Bisphenol A) on Radix balthica in lotic mesocosm were studied by De Kermoysan [7]. The authors observed a significant increase in total abundance and a modification of population structure at $100 \mu \mathrm{g} / \mathrm{L}$ of BPA. An increase of population growth rate induced by BPA is suspected. The study of the effects of cadmium on Lymnaea stagnalis reproduction in a laboratory study has shown that the number of eggs per egg mass and stages of embryo development were particularly sensitive end points [15]. Furthermore, gastropods endocrine system is principally under the control of neuropeptides [19] and their hormonal system resembles vertebrate hormonal systems [26]. So, endocrine disrupting effects revealed on these organisms could be eventually extrapolated to vertebrates.

Histology is one of the methods used to evaluate the effects of toxic substances on aquatic organisms [18,33]. Effects of endocrine disrupting chemicals on the reproduction of certain 
species of freshwater gastropods have also been revealed by histopathological analyses of gonads [12]. In some species, imposex was found $[1,13,24,29]$. As histopathological analyses provides further evidence on the eventual impairment of reproduction by endocrine disrupting chemicals, it seems important to incorporate them in ecotoxicological studies. Surprisingly, anatomical and histological characterization of the gametogenesis of most freshwater gastropods species in control conditions are not reported, even they are highly useful to eventually assess the effects of chemical substances on the reproduction of the organisms. In this context, we chose to study two gastropod species Lymnaea stagnalis (Linnaeus, 1758) and Radix balthica (Linnaeus, 1758) in order to specify some elements of their biology.

The pond snail (Lymnaea stagnalis) was recently introduced in our laboratory and is an ecologically relevant model species which is known to be sensitive to pollutants especially to endocrine disrupting chemicals $[5,6,10]$. The histological structure of the reproductive organs of Lymnaea stagnalis was described by $[2,3,27]$ and by [19] using the former name of the species, Helix palustris. In our study, the description has been reviewed and completed.

Radix baltica belongs to the same family as Limnaea stagnalis that is Lymnaedea [30]. The anatomy and histology of the gonads of Radix balthica have never been characterized. As this species is closely related to Lymnaea stagnalis, a comparison of the anatomy and histology of the reproductive organs has been made. Furthermore, this species is used as a model species in our mesocosm studies. As mentioned above, effects at the population level were reported after a 6 month exposure to an endocrine disrupting chemical [7]. As a phenomenon of "superfeminisation" of the individuals is suspected, histopathological analyses of the gonads of the contaminated individuals is necessary. Prior to this analysis, the study of the gonads of non-contaminated organism, reared in control conditions is thus fundamental.

\section{Material and methods}

Five adults of each species were fixed with Bouin's fluid for $72 \mathrm{~h}$. Size of the organisms were between 15 and $18 \mathrm{~mm}$ for Radix balthica and 28 to $30 \mathrm{~mm}$ for Lymnaea stagnalis. The Bouin fixation is essential in order to stabilize the tissue and cellular structures [28]. The liquid was composed of the following mixture: $75 \%$ of a saturated solution of picric acid (Fluka, Gillingham, United Kingdom), 20\% formaldehyde (Aldrich, Saint louis, United States-Missouri) and 5\% acetic acid (Carlo Erba, Val de Reuil, France). This mixture enables to both dissolve the shells and fix the tissues properly. To obtain a complete dehydration of the material, the samples were then rinsed with increasing alcohol concentrations (70\% to $100 \%$ ). Next, the "lightening" step was performed in using a solvent bath allowing the replacement of intracellular water with paraffin. Then $5-\mu \mathrm{m}$ sections were obtained using a microtome (Leica RM 2245,Wetzlar, Germany). They were then stained with
Groat hematoxylin (mixture v/v hemalum)(Sigma-Aldrich Aldrich, Saint Louis, Missouri USA) under acidic conditions and hematoxylin Sigma-Aldrich under alcoholic conditions, those dyes having a tinctorial affinity for nuclear acids. Eosin Diagnostic (RAL, Bordeaux Montesquieu, France) (1\% in an aqueous medium) was used in order to stain cytoplasms. The Nikon Eclipse 80i microscope (Nikon, Tokyo, Japan) was used for the observations.

\section{Results}

Anatomy and general description of the gametogenesis Phylogenetic classification of the two species is shortly presented in Table1, showing that these two species belong to the same family and that their differences reside only in the species and the genus.

Table 1. Taxonomic classification of Radix balthica and Lymnaea stagnalis based on Glöer, 2003.

\begin{tabular}{|l|}
\hline Kingdom: Animalia \\
Phylum: Mollusca \\
Class: Gastropoda \\
Subclass: Orthogastropoda \\
Order: Pulmonata \\
$\begin{array}{l}\text { Order: Pulmonata } \\
\text { Family: Lymnaeidae }\end{array}$ \\
$\qquad \quad$ R. balthca $\longrightarrow$ stagnalis $\longrightarrow \begin{array}{l}\text { Genus: Radix } \\
\text { Species: Radix balthica }\end{array}$ \\
$\quad \begin{array}{l}\text { Genus: Lymnaea } \\
\text { Species: Lymnaea stagnalis }\end{array}$ \\
\end{tabular}

The shell of Lymnaea stagnalis is massive, elongated and pointy with 6 to 8 spiral turns (H: 54, l:27) (Figure 3A).The shell of Radix balthica is subdiscoiled, belly shaped and appears like a droplet (Figure 2A). The apex is round and not as pointy as for Lymnaea stagnalis. It has three and a half spiral turns $(\mathrm{H}$ : 20, I:14) [14]. The mantle of Radix balthica has both pale and dark spots and has a dark line on the apical pole $[11,30]$. The foot is light green and covered by small shiny spots (Figure 2A) whereas the mantle and foot of Lymnaea stagnalis is clear and uniform (Figure 3A).

Gametogenesis of Radix balthica and Lymnaea stagnalis is summarized in Figure 1. Figures $\mathbf{2}$ and $\mathbf{3}$ illustrate the general anatomy of an individual and show a selection of histological sections of the gonads for Radix balthica and Lymnaea stagnalis respectively.

For both species, female and male germ cells are produced in a hermaphroditic gland called ovo-testis. This gland is relatively massive and is located in the apical whorl inside an accessory lobe which is wrapped around the hepatopancreas (Figure 1).

In this area, in both species, the beginning of the gametogenesis showed only female germinal cells, surrounding 


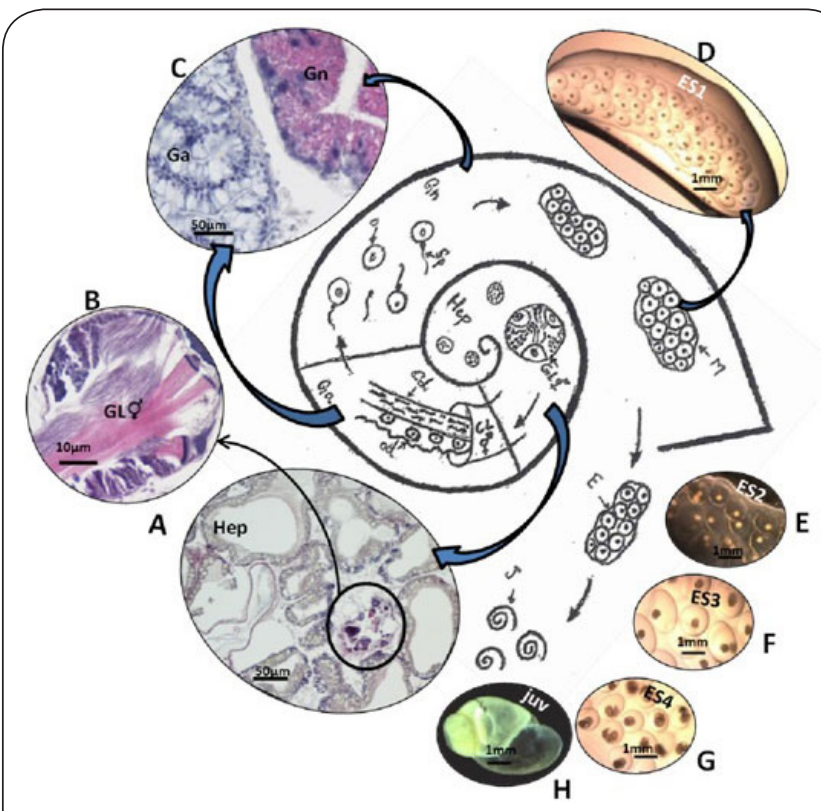

Figure 1. Simplified figure of the gametogenesis of Radix balthica and Lymnaea stagnalis.

A. Hep: Hepatopancreas; B. Gl: Hermaphroditic gland; C. Ga: Albumen gland, Gn: Nidamental gland; D. ES1: Stage 1 embryo; E. ES2: Stage 2 embryo; F. ES3: Stage 3 embryo; G. ES4: Stage 4 embryo; H. Juv: Juvenile, CL: Hermaphroditic duct, Cd: Spermiduct or vas deferens, Od: Oviduct; O: Oocyte, Sp: Spermatozoon, M: Egg mass. Scale bars, D, E, F, G, $\mathbf{H}=1 \mathrm{~mm} ; \mathbf{A}, \mathbf{C}=50 \mu \mathrm{m} ; \mathbf{B}=10 \mu \mathrm{m}$.

the hepatopancreatic epithelium which is wrapped in the secretion of the albumen gland (Figure 1A). The hermaphroditic gland matures from the apex to the foot. Histological sections enable to show side by side the two types of gametes. Spermatozoa and oocytes are both discharged by respectively the spermiduct and the oviduct in a junction where the secretion of the albumen gland is also deposited (Figures 1A-1C). Surrounded by the albumen secretions, the gametes continue their journey in the gland of nidation where fertilization occurs; and so oocytes are fertilized and grouped in masses which are then discharged through the genital pore located on the head near the mouth (Figure 1D). Embryogenesis is pursued ex-vivo and juveniles are released between 14 to 15 days depending on the environmental conditions (Figures 1E-1H).

\section{Histological characterization of the gametogenesis of Radix balthica and Lymnaea stagnalis}

For two species, oocyte differentiation is essential allowing these cells to achieve the vitellogenesis stage that favors the production of exogenous vitellogenin. The latter is a precursor of vitellus and induces oogenesis favoring fertilization and embryogenesis.

Female cells are contained in a follicular cord located on the basal lamina of the gonad. As they mature, they are pushed little by little through the oviduct (Figure 2D). They end up
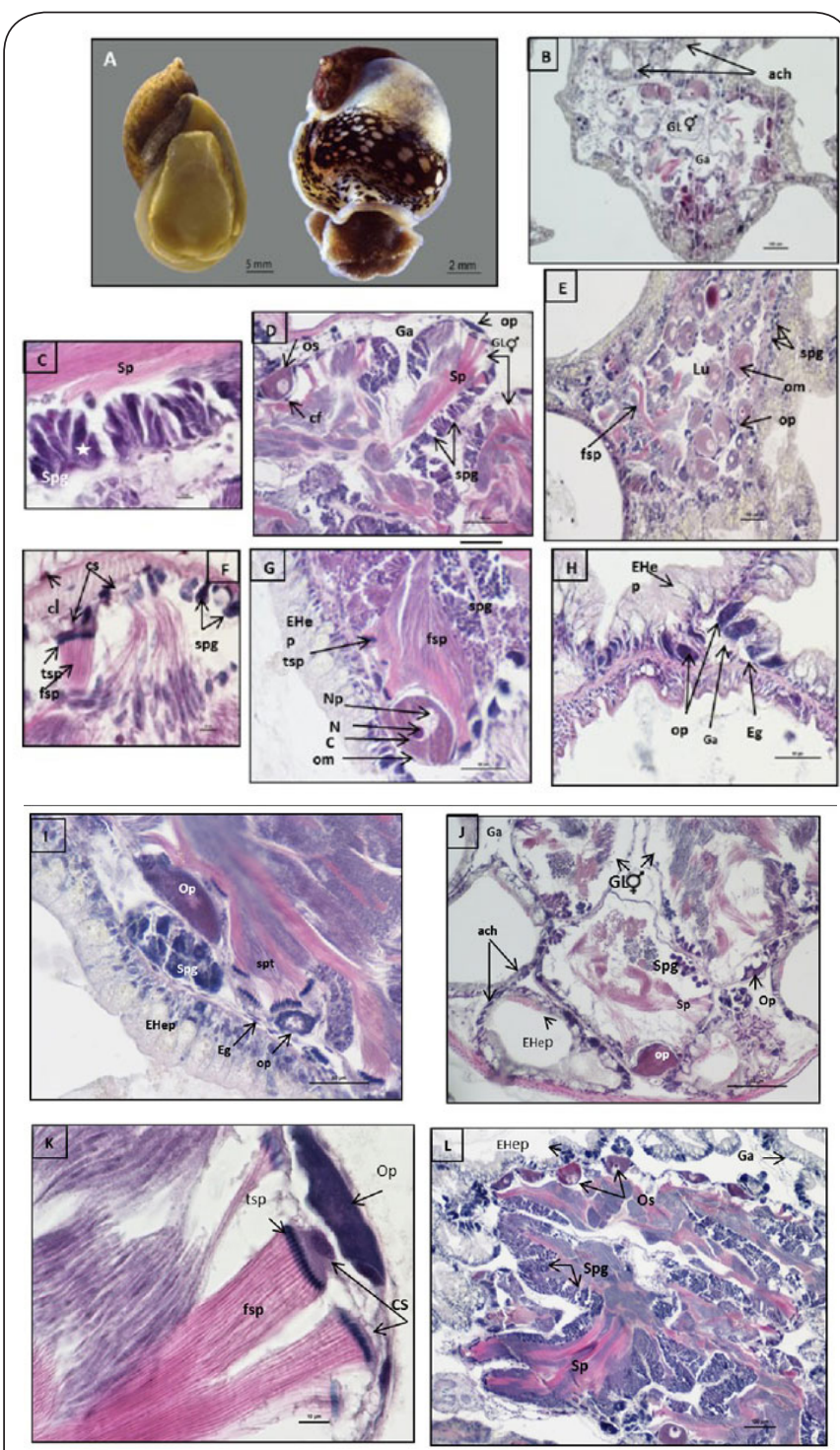

Figure 2. (A-H) Gonad histology of Radix balthica. A. Ventral view and general morphology of Radix balthica (Linnaeus, 1758). B-L: Transversal sections of Radix balthica; embedding paraffin; cutting width $4 \mu \mathrm{m}$; staining hematoxylin-eosin. B. Gl: Hermaphroditic gland, ach: Hepatopancreatic acini, Ga: Albumen gland; C. Sp: Spermatozoon, Spg: Spermatogonium star, Clustered spermatogonia. D. cf: Follicular cells, Os: Secondary oocyte, Ga: Albumen gland, Sp: Spermatozoon, spg: Clustered spermatogonia; E. fsp: Spermatozoon flagella, spg: Spermatogonium, op: Primary oocyte, om: Mature oocyte, Lu: Gland lumen; F. cl: Leydig cells, cs: Sertoli cells; G. Om: Mature oocyte, C: Cytoplasm, N: Cell nucleus, Np: Nucleoplasm, tsp: Head of the spermatozoon, EHep: Hepatopancreatic epithelium; H. Eg: Germinal epithelium; Scale bars, B, $\mathbf{E}=100 \mu \mathrm{m} ; \mathbf{D}, \mathbf{G}, \mathbf{H}=50 \mu \mathrm{m} ; \mathbf{C}, \mathbf{F}=10 \mu \mathrm{m}$. (I-L) Gonad histology of Radix balthica. I. op: Primary oocyte, Eg: Germinal epithelium, EHep: Hepatopancreatic epithelium, spg: Clustered spermatogonia, op: Primary oocyte, spt: spermatozoon; J. ach: Hepatopancreatic acini; K. tsp: Head of the spermatozoon, cs: Sertoli cells; L. EHep: Hepatopancreatic epithelium, Sp: Spermatozoon, Spg: Clustered spermatogonia, Os: Secondary oocyte; Scale bars, $\mathbf{L}=100 \mu \mathrm{m} ; \mathbf{I}, \mathbf{J}=50 \mu \mathrm{m} ; \mathbf{K}=10 \mu \mathrm{m}$. 


\section{in a gland of nidation where they are fertilized. Three types of Primary oocytes}

cells were observed.

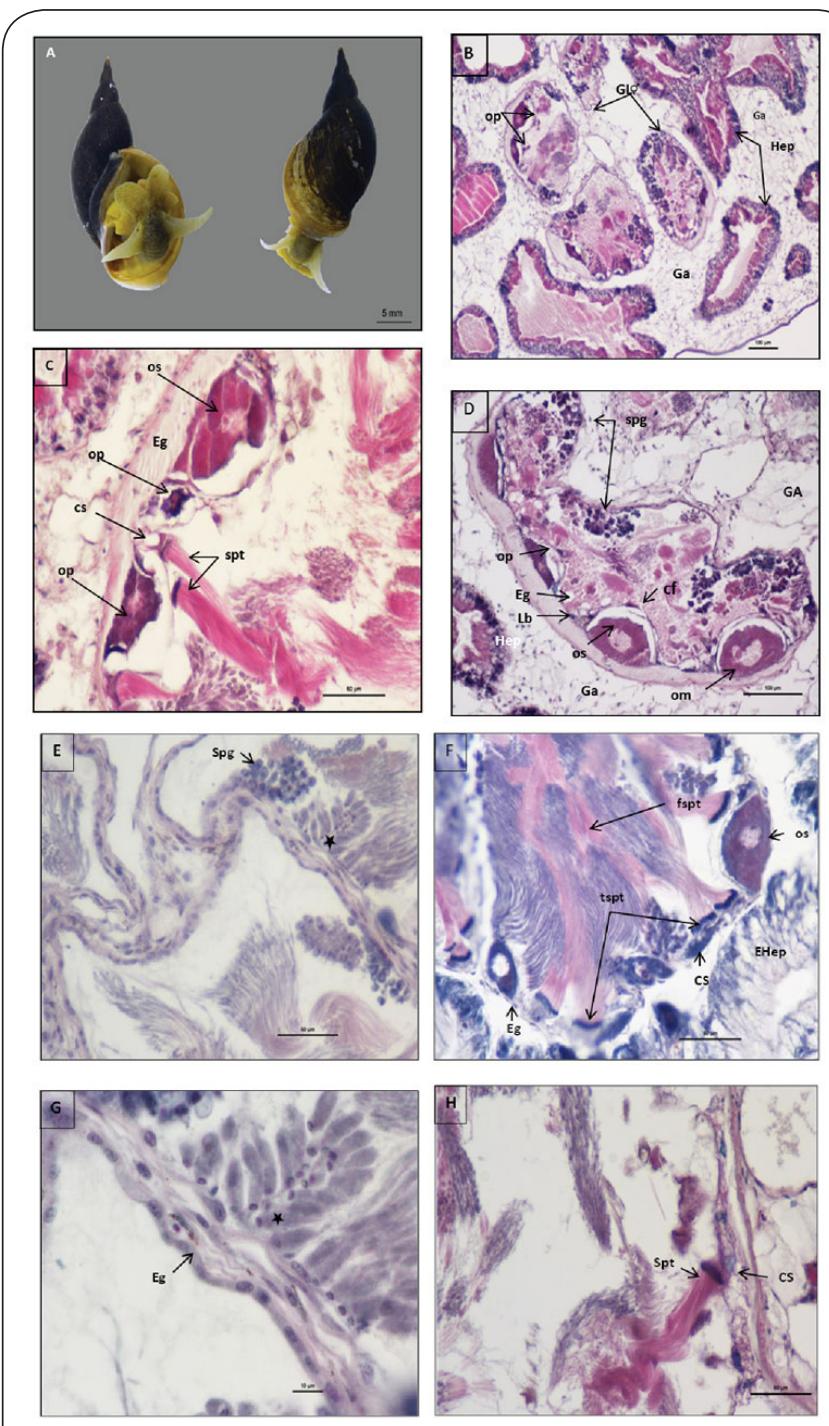

Figure 3. (A-D) Gonad histology of Lymnaea stagnalis. A. Ventral view and general morphology of Lymnaea stagnalis (Linnaeus, 1758). B-H: Transversal sections of Lymnaea stagnalis; embedding, paraffin; cutting width $4 \mu \mathrm{m}$; staining hematoxylin-eosin; B. op: Primary oocyte, GL: Hermaphroditic gland, Hep: Hepatopancreatic acini, Ga: Albumen gland; C. op: Primary oocyte, c: Sertoli cells, Eg: Germ epithelium, os: Secondary oocyte, Spt: Spermatozoon; D. om: Mature oocyte, os: Secondary oocyte, Lb: Basal lamina, Eg: Germinal epithelium, op: Primary oocyte, Spg: Spermatogonium, cf: Follicular cells, GA: Albumen gland; Scale bars, B, D=100 $\mu$; $\mathbf{C}=50 \mu \mathrm{m}=10 \mu \mathrm{m}$. $(\mathbf{E}-\mathbf{H})$ Gonad histology of Lymnaea stagnalis. E. Star: Clustered spermatogonia interwoven between the Sertoli cells; F. Eg: Germinal epithelium, tsp: Head of the spermatozoon, fsp: Spermatozoon flagella, os: Primary oocyte, EHep: Hepatopancreatic epithelium; G. Eg: Germinal epithelium; H. Spt: Spermatozoon, cs: Sertoli cells; Scale bars, E, $\mathbf{F}, \mathbf{H}=50 \mu \mathrm{m} ; \mathbf{G}=10 \mu \mathrm{m}$.
The cells are small and star-shaped. The central nucleus is slightly differentiated and the cytoplasm is basophilic and is subtly granular (Figures 2D, 2H, 2I, 2K and Figures 3C, 3D).

\section{Secondary oocytes}

Two types of oocytes can be distinguished: oocytes at the beginning of maturation and mature oocytes. Oocytes that have started maturation are called secondary oocytes. These cells of medium size, with a central basophilic nucleus, show a large cytoplasm (Figures 2D, 2E, 2L and Figures 3C, 3D, 3F).

\section{Mature oocytes}

They are large cells with a round central nucleus, pigmented, basophilic which is trapped in a lipid cavity that could be equal to 2 to 3 times the surface of the nucleus (Figures $2 \mathbf{G}$ and $3 \mathrm{D}$ ). At this stage, the cytoplasm of the cells is filled with lipid droplets and homogenous eosinophilic globules of vitellus.

Male germ line cells of the two species were observed in the seminiferous tubes which are separated by connective tissue in which interstitial Leydig cells can be found (Figure 2F). Oogonia are discharged onto the germ epithelium which is anchored on the Sertoli cells. The latter are bulky and form a pyramid that lies towards the lumen of the seminiferous tubes allowing the anchorage of spermatogonia thus favoring their nutrition and explaining their clustered form (Figures $2 \mathrm{~F}, 2 \mathrm{~K}$ and Figures $3 \mathrm{C}, 3 \mathrm{H}$ ). The male germ cells alternate with female germ cells (Figures 2C, 2D, 2F, 2I and Figures 3C, 3E-3G).

In the acini, a synchronized maturation of the male cells with the different stages of oogenesis of the female cells was observed (Figures 2D, 2G and Figures 3D, 3F). Indeed, female gametes rest on the acini epithelium cells and are surrounded with male gametes (Figures 2D, 21, 2L and Figures 3B, 3F). These gametes are in pre-meiotic phase and then multiply by mitosis after their differentiation and constantly stay in contact with the membranes of the acini cells.

\section{Spermatogonia}

They are large sized cells located at the border of the seminiferous tubes and anchored between the Sertoli cells. They are organized in clusters. These cells undergo different stages of maturation leading to the formation of spermatozoids that are released in the lumen of the seminiferous tubes (Figures 2C-2F and Figures 3E, 3G).

\section{Spermatozoids}

The spermatozoids are very long cells composed of two distinct parts visible under a stereomicroscope: the head and the flagella. The head is oviform, slightly flattened, anchored between the Sertoli cells whereas the eosiniphilic opposite part is tapered towards the lumen looking like ordered parallel silk filaments. This part contains the flagella which has the same structure for both species (Figure 2F, 2I, 2K and Figures $3 \mathrm{C}, 3 \mathrm{~F}, 3 \mathrm{H}$ ). 


\section{Discussion}

Our results enabled to gain more knowledge on the structure and functioning of the gonad of Radix balthica compared to Lymnaea stagnalis. The latter has been frequently used in many studies dealing with toxic effects of pollutants $[6,13,18]$. All the authors acknowledged that this species belongs to one of the most sensitive groups of aquatic organisms.

Even if no difference in the histology of the gonads has been observed, important morphological differences exist between the two species. They concern the shell structure, the presence of alternating pale and dark spots on the mantle, the green color of the foot, the bright spots on the foot for Radix balthica compared to Lymnaea stagnalis. Lymnaea stagnalis has a long shell $(\mathrm{H}=29-54 \mathrm{~mm})$ which is acuminated with 6 to 8 spiral towers, the last being bulky. Radix balthica has a globular shell with 4 to 5 spiral turns that increases rapidly, the last being very large.

This study allowed the description of the anatomy and internal structure of the gonad of Radix balthica in the absence of contamination. The next step is a histopathological analysis of organisms exposed to selected chemicals in order to eventually identify their effects on the reproduction of this species.

Radix balthica seems a possible candidate as a new model species allowing the identification of effects of certain chemical substance on the reproduction of gastropod mollusks, as the number of studies involving this species is growing, for example, Schniebs [30] studied the genetic variability of the cyt-b gene following a method used by Tamura [35]. They found a difference in length of the two fragments of the gene of $2.24 \%$ between the two species. These authors also mentioned a difference in the length and position of the bursa copulatrix. It is short and near the pericardia for Lymnaea stagnalis and long and near the provaginal duct for Radix balthica [30,31].

Important morphological differences exist between the two species. Despite this, the gonads of the two gastropods species have similar histological structure. In both species, spermatogonia are clustered, spermatozoids are anchored between the Sertoli cells and the male cells alternate with the female cells that rest on the epithelium of the hermaphroditic gland as already observed in the gastropod [34]. This study shows that the gonads of the two gastropods species, Radix balthica and Lymnaea stagnalis have similar histological structure. Indeed, in both species, the female cells rest on the epithelium of the hermaphroditic gland and alternate with the clustered structure of spermatogonia and the spermatozoids that are anchored between the Sertoli cells.

This study is a prerequisite for any further histopathological studies on contaminated individuals.

\section{Competing interests}

The authors declare that they have no competing interests.
Authors' contributions

\begin{tabular}{|l|c|c|c|c|c|c|c|}
\hline Authors' contributions & KTA & SJ & JG & PB & JME & JMP & OG \\
\hline Research concept and design & $\checkmark$ & -- & -- & -- & -- & -- & -- \\
\hline Collection and/or assembly of data & $\checkmark$ & $\checkmark$ & -- & -- & -- & -- & -- \\
\hline Data analysis and interpretation & $\checkmark$ & -- & -- & -- & -- & -- & -- \\
\hline Writing the article & $\checkmark$ & $\checkmark$ & -- & -- & -- & -- & -- \\
\hline Critical revision of the article & -- & -- & $\checkmark$ & $\checkmark$ & $\checkmark$ & -- & -- \\
\hline Final approval of article & -- & -- & -- & -- & -- & $\checkmark$ & $\checkmark$ \\
\hline Statistical analysis & -- & -- & -- & -- & -- & -- & -- \\
\hline
\end{tabular}

Acknowledgement

Authors acknowledge the support of the French Ministry in charge of Ecology and Sustainable Development for this study within the frame work of Programme 190. The authors are greatly indebted to Jacques Mouthon and Maxence Forcellini, both researchers in Ecohydrology of macroinvertebrates at IRSTEA Lyon Villeurbanne for the taxonomic determination of the two taxon's and advice on literature data.

Publication history

EIC: Gaetano Giuseppe Magro, University of Catania, Italy. Received: 14-Feb-2017 Final Revised: 19-Apr-2017

Accepted: 01-May-2017 Published: 15-May-2017

\section{References}

1. Axiak V, Vella A J, Micallef D, Chircop P and Mintoff B. Imposex in Hexaplertrztnculus (Gastropoda: Muricidae): first results from biomonitoring of tributyltin contaminationin the Mediterranean. Mar. Biol. 1995; 821:685-691.

2. Baudelot. Recherches sur l'appareil génital des Mollusques gastéropodes. Ann. Se. nat. Zool. 1863; 19.

3. Baker FC. Notes on the genitalia of Lymnaea. Amer. Natur. 1905; 39:665679.

4. Bluzat $R$ and Seuge J. Chronic intoxication by an herbicide, 2,4,5-trichlorophenoxyacetic acid, in the pond snail, Lymnaea stagnalis L. Environ Res. 1983; 31:440-7. I PubMed

5. Coutellec MA and Lagadic L. Effects of self-fertilization, environmental stress and exposure to xenobiotics on fitness-related traits of the freshwater snail Lymnaea stagnalis. Ecotoxicology. 2006; 15:199-213. | Article I PubMed

6. Czech P, Weber K and Dietrich DR. Effects of endocrine modulating substances on reproduction in the hermaphroditic snail Lymnaea stagnalis L. Aquat Toxicol. 2001; 53:103-14. | Article | PubMed

7. de Kermoysan G, Joachim S, Baudoin P, Lonjaret M, Tebby C, Lesaulnier F, Lestremau F, Chatellier C, Akrour Z, Pheron E, Porcher JM, Pery AR and Beaudouin R. Effects of bisphenol A on different trophic levels in a lotic experimental ecosystem. Aquat Toxicol. 2013; 144-145:186-98. | Article I PubMed

8. Dillon RT. The ecology of freshwater molluscs. Cambridge University Press, Eds. 2000; 509.

9. Dobranskyte A, Jugdaohsingh R, Mccrohan CR, Stuchlik E, Powell JJ and White KN. Effect of humic acid on water chemistry, bioavailability and toxicity of aluminium in the freshwater snail, Lymnaea stagnalis, at neutral pH. Environ Pollut. 2006; 140:340-7. I Article I PubMed

10. Ducrot V, Teixeira-Alves M, Lopes C, Delignette-Muller ML, Charles S and Lagadic L. Development of partial life-cycle experiments to assess the effects of endocrine disruptors on the freshwater gastropod Lymnaea stagnalis: a case-study with vinclozolin. Ecotoxicology. 2010; 19:1312-21. | Article | PubMed

11. Falniowski A. Pigmentation of the mantle border in polish representatives of the subgenus Radix (Lymnaeidae, Basommatophora, Gastropoda). Basteria. 1980; 44:3-8. I Pdf 
12. Gagnaire B, Gagne F, Andre C, Blaise C, Abbaci K, Budzinski H, Devier MH and Garric J. Development of biomarkers of stress related to endocrine disruption in gastropods: alkali-labile phosphates, protein-bound lipids and vitellogenin-like proteins. Aquat Toxicol. 2009; 92:155-67. | Article I PubMed

13. Gibbs PE, Pascoe PL and Bryan GW. Tributyltin-induced imposex in stenoglossan gastropods: pathological effects on the female reproductive system. Comparative Comp. Biochem. Phys C. 1991; 100:231-235. | Article

14. Glöer P. Süsswassermollusken: [Freshwater Molluscs: An identification key for the freshwater mussels and snails of germany]. 2015.

15. Gomot A. Toxic effects of cadmium on reproduction, development, and hatching in the freshwater snail Lymnaea stagnalis for water quality monitoring. Ecotoxicol Environ Saf. 1998; 41:288-97. | Article | PubMed

16. Gust M, Garric J, Giamberini L, Mons R, Abbaci K, Garnier F and Buronfosse T. Sensitivity of New Zealand mudsnail Potamopyrgus antipodarum (Gray) to a specific aromatase inhibitor. Chemosphere. 2010; 79:47-53. | Article I PubMed

17. Gust M, Buronfosse T, Geffard O, Coquery M, Mons R, Abbaci K, Giamberini $L$ and Garric J. Comprehensive biological effects of a complex field poly-metallic pollution gradient on the New Zealand mudsnail Potamopyrgus antipodarum (Gray). Aquat Toxicol. 2011; 101:100-8. | Article | PubMed

18. Hinton D E, Kendall M W and Silver B B. Use of histologic and histochemical assessments in the prognosis of the effects of aquatic pollutants. In Cairns J. Jr. \& Dickson K L, E D, Biological methods for the assessment of water quality.Astm special pub. 528, Philadelphia. 1973; Pa: 194 208. | Article

19. Joosse J. The hormones of molluscs. In H. Laufer (Ed.), endocrinology of selected invertebrate types. 1988; 89-140. New York: Alan R Liss.

20. LydeardC, Cowie R H, Ponder W F,Bogan A E, Bouchet P, Clark S A, Cummings K S, Frest T J, Gargominy O, Herbert D G, Hershler R, Perez K $E$, Roth $B$, Seddon $M$, Strong $E E$ and Thompson $F$ G. The global decline of nonmarine mollusks. Bioscience. 2004; 54:321-330. | Article

21. Martoja R and Martoja-Pierson M. Initiation aux techniques d'histologie animale, Masson, Paris. 1967.

22. Matthiessen P. An assessment of endocrine disruption in mollusks and the potential for developing internationally standardized mollusk life cycle test guidelines. Integr Environ Assess Manag. 2008; 4:274-84. | Article I PubMed

23. Oberdorster $E$ and McClellan-Green P. Mechanisms of imposex induction in the mud snail, Ilyanassa obsoleta: TBT as a neurotoxin and aromatase inhibitor. Mar Environ Res. 2002; 54:715-8. | Article | PubMed

24. Oehlmann J, Schulte-Oehlmann U, Tillmann M and Markert B. Effects of endocrine disruptors on prosobranche snails (Mollusca: Gastropoda) In the laboratory. Part I: Bisphenol A and octyphenol as xeno-estrogens. Ecotoxicology. 2000; 9:383-397.

25. Oehlmann J, Fioroni P, Stroben E and Markerta B. Tributyltin (TBT) effects on Ocinebrinaaciculata (gastropoda: muricidae): imposex development, sterilization, sex change and population decline. Sci.Total Environ. 1996 ; 188:205-223. | Article

26. Porte C, Janer G, Lorusso LC, Ortiz-Zarragoitia M, Cajaraville MP, Fossi MC and Canesi L. Endocrine disruptors in marine organisms: approaches and perspectives. Comp Biochem Physiol C Toxicol Pharmacol. 2006; 143:303-15. | Article | PubMed

27. Prevost C. De la génération chez la Limnée : Helixpalustris. Mém. Soc. Phys. Hist. Nat. Genève. 1828.

28. Salanki J, Farkas A, Kamardina T and Rozsa KS. Molluscs in biological monitoring of water quality. Toxicol Lett. 2003; 140-141:403-10. | Article I PubMed

29. Schulte-Oehlmann U, Tillmann M, Markert B, Oehlmann J, Watermann $B$ and Scherf S. Effects of endocrine disruptors on prosobranch snails (Mollusca: Gastropoda) in the laboratory. Part II: Triphenyltin as a xenoandrogen. Ecotoxicology. 2000; 9:399-412. I PubMed

30. Schniebs K, Glöer P, Schniebs K and Hundsdoerfer A K. Intraspecific morphological and genetic variability in Radix balthica (Linnaeus 1758) (Gastropoda: Basommatophora: Lymnaeidae) with morphological comparison to other European Radix species. J. Conchol. 2011; 40:657677.

31. Schniebs K, Glöer P, Schniebs K, Glöer P and Hundsdoerfer A K. Intraspecific morphological and genetic variability in the european freshwater snail Radix labiata (Rossmaessler, 1835) (Gastropoda: Basommatophora: Lymnaeidae). Contrib Zool.2013; 82:55-68. | Pdf

32. Smith BS. Sexuality in the american mud snail, Nassariusobsoletus Say. Proc MalacSocLond. 1971; 39:377-378. I Article

33. Sprague J B. Measuremcnt of pollutant toxicity to fish III. Sublethal effects and safe concentrations. 14 ater Res. 1971; 5:245-266. | Article

34. Tair-Abbaci K and Garric J. Histological study of gonadogenesis in Potamopyrgus antipodarum and Valvata piscinalis. J CytolHisto. 2010; 3:1-7. I Pdf

35. Tamura K, Dudley J, Nei M and Kumar S. MEGA4: Molecular Evolutionary Genetics Analysis (MEGA) software version 4.0. Mol Biol Evol. 2007; 24:1596-9. | Article | PubMed

\section{Citation:}

Tair-Abbaci K, Joachim S, Garric J, Boisseaux P, Exbrayat J-M, Porcher J-M and Geffard O. Anatomical and histological characterization of the gametogenesis of Radix balthica (linnaeus, 1758) in comparison with Lymnaea stagnalis (linnaeus, 1758). J Histol Histopathol. 2017; 4:5. http://dx.doi.org/10.7243/2055-091X-4-5 